\title{
Numerical diagnostic of the circulation in the Santos Bight with COROAS hydrographic data
}

\author{
Mauro Cirano \& Edmo José Dias Campos
}

Instituto Oceanográfico da Universidade de São Paulo

(Caixa Postal 66149, 05389-970, São Paulo, SP, Brasil)

\begin{abstract}
- Abstract: This work represents part of the analyses of the data generated during the first two mesoscale hydrographic cruises of COROAS Project: one during the Summer and the other during the Winter of 1993. The area surveyed during these cruises is the region of the South Brazil Bight (or Santos Bight) limited at the coast by the cities of Ubatuba and Iguape, extending from the $50 \mathrm{~m}$ isobath to oceanic regions with depths greater than $2500 \mathrm{~m}$. The main goal of this work consisted of the adaptation of the Princeton Ocean Model to the area of study, including realistic topography, observed thermohaline structure and open boundaries. Using this model, a set of diagnostic experiments was realized using density structures based on the COROAS hydrographic data. The baroclinic velocity fields obtained, as expected from preliminary analyses of the thermohaline structures, showed similar features for the Brazil Current in boin seasonal cruises. The results show an intrusion of Tropical Water over the continental shelf in the region between Ubatuba and Santos, both during the Summer and the Winter cruises. The results also suggest the penetration of the South Atlantic Central Water, underneath the Tropical Water, to the external part of the continental shelf in both occasions.
\end{abstract}

- Resumo: Este artigo representa parte das análises desenvolvidas com os dados hidrográficos coletados durante os dois primeiros cruzeiros do sub-projeto Hidrografia de Meso-escala (HM) do Projeto COROAS: o primeiro no verão e o outro no inverno de 1993. A área amostrada nos dois cruzeiros é limitada na costa pelas cidades de Iguape e Ubatuba, estendendo-se da isóbata de $50 \mathrm{~m}$ até regiōes oceânicas com mais de $2500 \mathrm{~m}$ de profundidade. O objetivo central deste trabalho resumiu-se na adaptação do Princeton Ocean Model para a regiāo de estudo, incluindo batimetria real, os campos termohalinos observados e contornos abertos. Usando-se esse modelo, realizou-se um conjunto de experimentos diagnósticos usando estruturas de densidade baseadas nos dados hidrográficos do COROAS. Os campos baroclínicos de correntes obtidos, de acordo com o esperado a partir de análises das estruturas termohalinas, apresentaram feiçōes para a Corrente do Brasil bastantes similiares em ambos os cruzeiros. Esses resultados sugerem uma intrusão da Água Tropical sobre a plataforma continental na regiāo entre Ubatuba e Santos, tanto durante o cruzeiro de verão quanto no de inverno. Os resultados sugerem, também, penetração da Água Central do Atlântico Sul sobre a plataforma nas duas ocasiōes.

- Descriptors: Brazil Current, Thermohaline structure, Santos bight, $\sigma$-coordinate, Coroas Project.

\section{Introduction}

The large-scale circulation in the South Atlantic ocean has been relatively well investigated since the Meteor expedition in the 1920's. However, until recently most of the

$\overline{\text { Contr. no. } 800}$ do Inst. oceanogr. da Usp. oceanographic studies in that part of the ocean were aimed at the general aspects of the circulation, of the main patterns of temperature and salinity fields, and of the characteristic water masses (Reid et al., 1977; Garfield III, 1990; Peterson \& Stramma, 1991). At the mesoscale, several studies had been developed in the past twenty years or so (e.g.: Signorini, 1976, 1978; Miranda \& Castro Filho, 1979, 1982; Evans et al., 1983; Miranda, 1985; Signorini et 
al., 1989; Campos et al., 1994, 1995), but in general, these studies were concentrated in specific regions, mainly between Cabo de São Tomé and Rio de Janeiro.

With the advent of the recent international programs, such as the World Ocean Circulation Experiment (WOCE), the oceanographic community started to look more intensively at the smaller scale features, especially in the western region of the ocean near the coastline of South America. In this respect, one of the first Brazilian research efforts to look at mesoscale processes in the Brazil Current (BC) region following the strict WOCE specifications is the COROAS (Circulação Oceânica na Região Oeste do Atlântico Sul or Oceanic Circulation in the Western Region of the South Atlantic) experiment (Cirano, 1995; Silva, 1995; Ikeda \& Campos, 1995; Campos, 1995).
One component of the COROAS project is a mesoscale hydrographic (HM) survey of the South Brazil or Santos Bight region between $23^{\circ}$ and $27^{\circ}$, encompassing the continental shelf and the adjacent deep ocean. This study was carried out during three oceanographic cruises on board the University of São Paulo's R/V. "Prof. W. Besnard", the first (HM1) from Jan/22 to Feb/04/93; the second (HM2) from Jul/15 to Jul/29/93; and the third (HM3) from Jan/15 to Jan/29/94. During each of these cruises, approximately one hundred hydrographic stations for CTD (Conductivity-Temperature-Depth) profiling were occupied. Figure 1 shows the location of these stations during the first two cruises (HM1 and HM2), data of which are analyzed in the present work.

In this article, the thermohaline data obtained during HM1 and HM2 are used to initialize a diagnostic

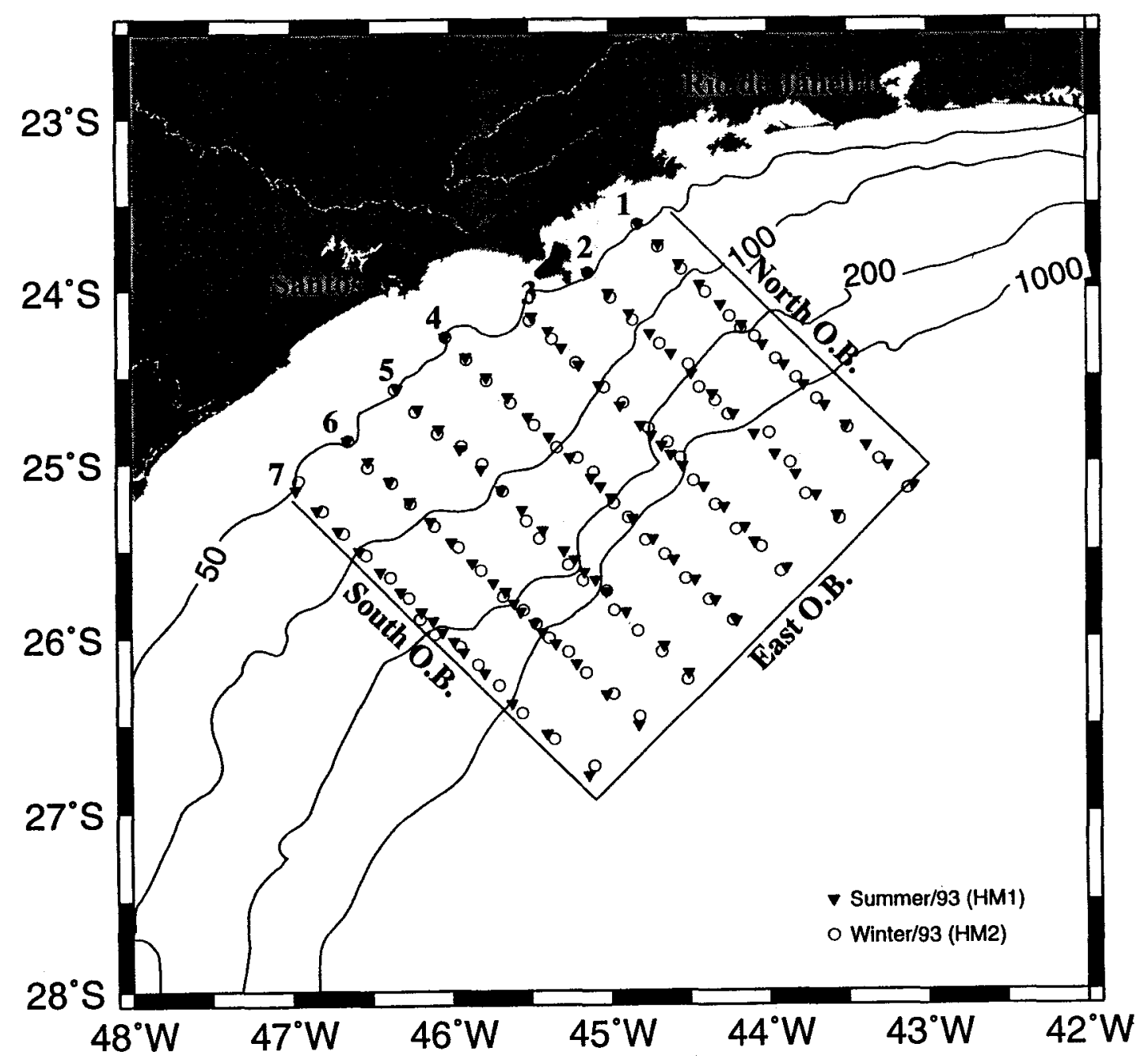

Fig. 1. The area of study of HM1 and HM2, showing the hydrographic stations (triangles and circles), the transects and the location of the open boundaries for the grid used in the numerical experiments of POM. 
implementation of the Princeton Ocean Model (POM) to the region surveyed, in a study of the flow associated with the observed mass field. The rationale for this approach is that the chosen numerical model (POM) uses the full momentum equation to compute the velocity field, while the classical geostrophic approaches, such as the dynamical method, employ only two terms: Coriolis and pressure gradient. Consequently, one would expect that results produced by the numerical model should be more realistic.

\section{The Brazil current features in the area of study}

The Brazil Current originates at the bifurcation of South Equatorial Current and flows southwards along the Brazilian coast to the Subtropical Convergence, at approximately $38^{\circ} \mathrm{S}$ (Peterson \& Stramma, 1991). Compared with its North Atlantic counterpart (the Gulf Stream), the BC presents a much weaker volume transport, which is explained by Stommel (1965) to be a consequence of the opposite directions of wind-driven and thermohaline flows in the subtropical South Atlantic. The actual transport values, mainly estimated from hydrographic data, are in general up to $10-12 \mathrm{~Sv}$ in the region of the Santos Bight (Campos et al., 1995).

The thermohaline structure of the Brazil Current is composed by two water masses flowing southwards: the warm salty Tropical Water (TW) (Emilsson, 1961), with temperatures $\mathrm{T}>20^{\circ} \mathrm{C}$ and salinities $\mathrm{S}>36$, flowing above the pycnocline; and the South Atlantic Central Water (SACW) (Sverdrup et al., 1942; Thomsen, 1962; Miranda, 1985), which flows to the south within the thermocline region, with $6^{\circ} \mathrm{C}<\mathrm{T}<20^{\circ} \mathrm{C}$ and $34.6<\mathrm{S}<36$. According to the classical picture, below the Brazil Current, in increasing depth, the water masses are those represented by the Antarctic Intermediate Water (AAIW): $3^{\circ} \mathrm{C}<\mathrm{T}<$ $6^{\circ} \mathrm{C}$ and $34.2<\mathrm{S}<34.6$; the North Atlantic Deep Water (NADW): $3^{\circ} \mathrm{C}<\mathrm{T}<4^{\circ} \mathrm{C}$ and $34.6<\mathrm{S}<35$; and the Antarctic Bottom Water (AABW), waters with temperature $\mathrm{T}<3^{\circ} \mathrm{C}$ and salinities $\mathrm{S}<35$.

The present knowledge of the $\mathrm{BC}$ is based mainly in results of gcostrophic calculations with observed thermohaline data obtained with Nansen bottles. Only recently CTD probes have been used in the region (Campos et al., 1994, 1995) and very few direct measurements have been performed so far. Numerical data are mainly from a few regional models or from global models with poor resolution. Among these studies, Mellor et al. (1982) computed the Ekman, thermohaline and bottom transports in a global model which barely resolved mesoscale features near the South American coast. Campos \& Olson (1991), using a basin scale implementation of an isopycnic coordinate model described the Brazil Current as a low transport current with mesoscale eddies as energetic as those observed in the Gulf Stream. Climatological annual mean values of temperature and salinity of Levitus (1982), and the climatological wind stress data of Hellerman and Rosenstein (1983) have been used by Semtner \& Chervin (1988) and Matano \& Philander (1993) in global and basin-scale models with somewhat good resolution of mesoscale processes in the region focused on the present paper. However, specific mesoscale implementations of "state-of-the-art" models, such as the one discussed here, are practically nonexistent in the literature. The regional numeric models applied for this specific area are represented by Harari (1984), Castro Filho (1985), Lorenzzetti et al. (1988) and Stech (1989). These models fail to describe accurately the Brazil Current, because they are either barotropic or linear.

\section{Material and methods}

\section{The hydrographic data}

As seen in Figure 1, the coastline in the region of study is oriented almost in the NE-SW direction. In that region, the Brazil Current is usually found near the shelf break (200 $\mathrm{m}$ isobath), meandering in a very energetic pattern, probably due to the abrupt change in coastline direction near Cabo Frio (RJ). The HM transects were planned to be approximately perpendicular to the shelf break in order to explore the geostrophy of the alongisobath component of the flow, but with a reasonable distance between consecutive transects (approximately 50 $\mathrm{km}$ ) for resolving also the along-isobath variability. Each transect extended from the $50 \mathrm{~m}$ isobath to regions with depth of the order of $2500 \mathrm{~m}$. The stations along each of the seven transects of Figure 1 were spaced approximately 17 $\mathrm{km}$ apart, except near the shelf break, where a $10 \mathrm{~km}$ spacing was adopted for better resolution of the complex dynamics of the region. In each station a CTD probe was used to collect information on the thermohaline structure of the water column. The temperature and salinity data obtained in each of these stations wcre used to compute water density.

\section{The numerical model}

As indicated in the introduction, the central idea of this work is to usea numerical model, in diagnostic mode, to obtain the baroclinic velocities associated with the observed mass field. The model employed is the $\sigma$-coordinate POM (Blumberg \& Mellor, 1987; Mellor, 1993), which is 
particularly suited for modelling regions with strong bathymetric gradients, such as the shelf break and slope regions. The POM is a three-dimensional, primitive equation model, using a second-moment turbulence closure scheme (Mellor \& Yamada, 1982) to give more realistic surface and bottom Ekman layers.

For the experiments reported in this article, the model was adapted to the region, including the real bottom topography, in a grid covering the area surveyed by the oceanographic cruises HM1 and HM2 (Fig. 1). The origin of the $x-y$ coordinate system was placed at $\left(47^{\circ} 33^{\prime} \mathrm{W}\right.$, $24^{\circ} 42^{\prime} \mathrm{S}$ ) and the axes were rotated by an angle of $45^{\circ}$, in order to have the $y$-axis oriented approximately in the alongshore direction. The $\beta$-plane approximation was used and the grid points were equally spaced in the horizontal, with a $10 \mathrm{~km}$ grid spacing. Horizontally, the domain dimensions were $300 \mathrm{~km}$ in the $y$ direction and $350 \mathrm{~km}$ in the $x$ direction. In the vertical, $18 \sigma$-levels were used (Table 1), with exponential distribution in the uppermost five levels and linear distribution in the remaining ones. Regions with depths less than $50 \mathrm{~m}$ were considered dry areas while depths greater than $2000 \mathrm{~m}$ were reduced to $2000 \mathrm{~m}$. For this spatial setting, the CFL (Courant-Friedrichs-Levy) criterion suggests, for the barotropic mode, a maximum time step interval of $25 \mathrm{~s}$ (the model integrates separately the external and internal modes). The effective value, however, was focused to be $15 \mathrm{~s}$. The corresponding internal time step, used to

Table 1. Vertical distribution of the sigma levels. Each number represents a fraction of the local depth, measured from the surface. Level 1 is the ocean surface and level 18 is the bottom floor

\begin{tabular}{|c|c|c|c|}
\hline Level & $\sigma$ & Level & $\sigma$ \\
\hline 1 & 0.000 & 10 & 0.429 \\
2 & 0.009 & 11 & 0.500 \\
3 & 0.018 & 12 & 0.571 \\
4 & 0.036 & 13 & 0.643 \\
5 & 0.071 & 14 & 0.714 \\
6 & 0.143 & 15 & 0.786 \\
7 & 0.214 & 16 & 0.857 \\
8 & 0.286 & 17 & 0.929 \\
9 & 0.357 & 18 & 1.000 \\
\hline
\end{tabular}

upgrade the baroclinic modes, was equal to $300 \mathrm{~s}$. In all experiments, the Smagorinsky's formulation (Smagorinsky, 1963) was used for horizontal diffusion, the local grid size and the velocity gradients are used to calculate the horizontal diffusivity.

The hydrographic (temperature and salinity) data collected during the first two COROAS mesoscale cruises were interpolated to each point of the model's three dimensional grid and a set of experiments was run in the diagnostic mode. That is, the mass structure was kept constant all the time, while the velocity field, spun up from rest, eventually adjusted to this prescribed thermohaline distribution.

\section{Boundary conditions}

A common problem in limited-area implementations of numerical models is the proper specification of boundary conditions. These conditions, which should "transmit" to the area under investigation the effects of remote forcings, are usually in the form of prescribed fluxes, thermohaline distribution and sea surface elevation. In the present case, since the thermohaline field is kept constant during all the experiments, the boundary conditions were taken from an assumed total barotropic volume transport across the open boundaries and associated sea surface elevation.

For the sea surface elevation, the gradient condition was used, eliminating the gradient of the surface height across the boundaries. The dynamic effect of this condition is the elimination of the geostrophic velocity parallel to the boundary, at the boundary points. For the normal component of the external velocity, in some of the experiments an imposed mass inflow/outflow was prescribed. This procedure was used because the main interest was the baroclinic field, which is obtained subtracting the barotropic field from the total one.

Assuming that the barotropic field exchanges little energy with the baroclinic field, then this approach would be reasonable. Thus, in order to test the validity of this assumption, experiments with different barotropic ficlds were carried out. For each cruise, the model was run with two different values of the barotropic volume transport across the open boundaries: $10 \mathrm{~Sv}$ and $0 \mathrm{~Sv}$. The associated velocity distribution (in the case of $10 \mathrm{~Sv}$ ) along the north and south boundaries are shown in Figure 2.

For the tangential component of the external and internal velocities, boundary conditions were applied only for the non-linear advective terms. For the normal component of the internal mode of the velocity, a Sommerfeld-like radiative condition (Sommerfeld, 1949) was applied. This condition is described as a gravity-wave radiative condition (Chapman, 1985). 


\section{Velocity profiles}

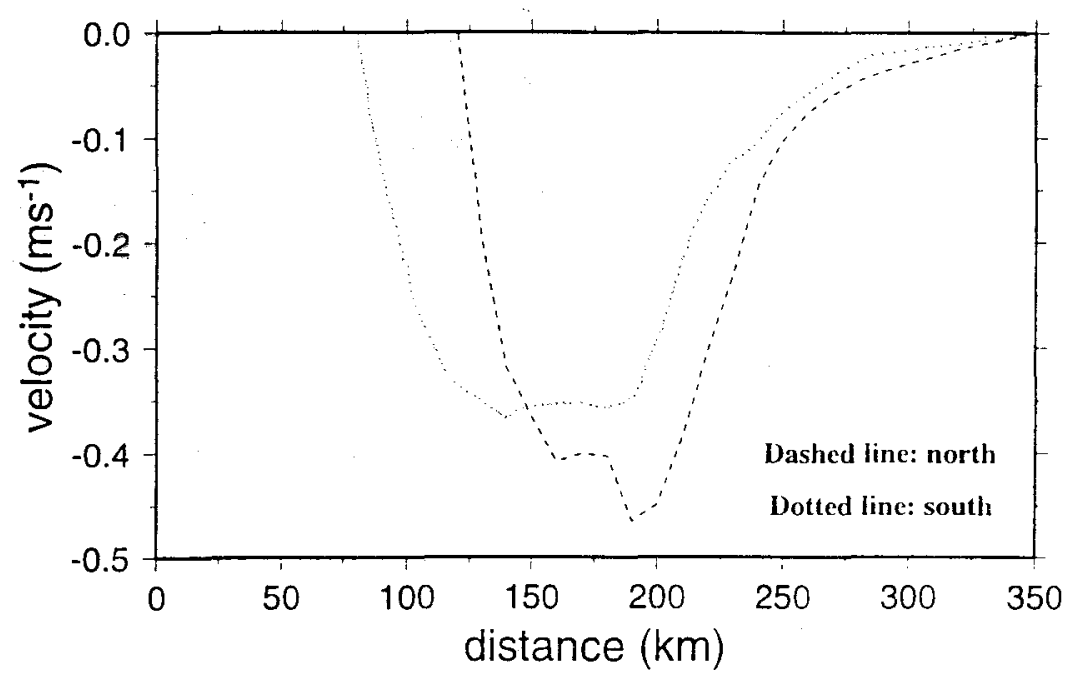

Fig. 2. Velocity distribution along the north and south boundaries, based on the imposed transport of $10 \mathrm{SV}$.

\section{Model initialization}

In this article four experiments are discussed. They were carried out with the objective of, first, to compare the methodology adopted, and second, to evaluate the seasonality between the HM1 and HM2 cruises. For each cruise, two experiments were done, one with prescribed mass inflow/outflow, and another with no flow across the open boundaries. The two first experiments, labeled EXP1 (with inflow/outflow) and EXP2 (with no inflow/outflow), refer to the summer cruise (HM1). The last two, EXP3 (with inflow/outflow) and EXP4 (without flow across the boundaries), refer to the winter cruise (HM2). The Table 2 summarizes the experiments.

Part of the thermohaline structures used in the model initialization are shown in vertical profiles for both HM1 (Fig. 3) and HM2 (Fig. 4). In these figures, the upper panel represents the northern part of the domain, the middle one shows transect in the central part, and the lower one represents the southern boundary.

Table 2. Summary of the numerical experiments

\begin{tabular}{|c|c|c|}
\hline Cruise & Experiment & \multicolumn{1}{|c|}{ Description } \\
\hline \hline \multirow{2}{*}{ HM1 } & EXP1 & southward barotropic transport of $10 \mathrm{~Sv}$ \\
\cline { 2 - 3 } & EXP2 & no barotropic transport \\
\hline \multirow{2}{*}{ HM2 } & EXP3 & southward barotropic transport of $10 \mathrm{~Sv}$ \\
\cline { 2 - 3 } & EXP4 & no barotropic transport \\
\hline
\end{tabular}

In all experiments (EXP1 through EXP4) the model was allowed to run for 15 simulation days. The time-history of the basin- averaged kinetic energy during the four runs are shown in Figure 5. In all cases the model reached an equilibrium state after approximately five simulation days.

\section{Results}

\section{The summer cruise - HM1}

Based on a crude analysis of the thermohaline structure along Transect 1 (Fig. 3), according to the values of water properties proposed by Miranda (1985), one would expect to find the Brazil Current front located near the coast; the Tropical Water occupying the upper $150 \mathrm{~m}$, in oceanic regions; and the SACW in the thermocline region, below $150 \mathrm{~m}$ of depth. It also seems to be clear, from the upper panel of Figure 3, that there is a core of SACW in the continental shelf region, near the bottom, which is not connected to the water with the same characteristics in the deeper oceanic region. On Transect 4 (middle panel of Fig. 3), the Brazil Current front is not so close to the coast, but one could still identify the same core of SACW over the shelf, separated from the oceanic one by the Brazil Current front. In the southern part of the domain (lower panel of Fig. 3), with the Brazil Current front located farther from the coast, one can notice that now there is a clear connection between the SACW located over the shelf and that located in oceanic regions. 

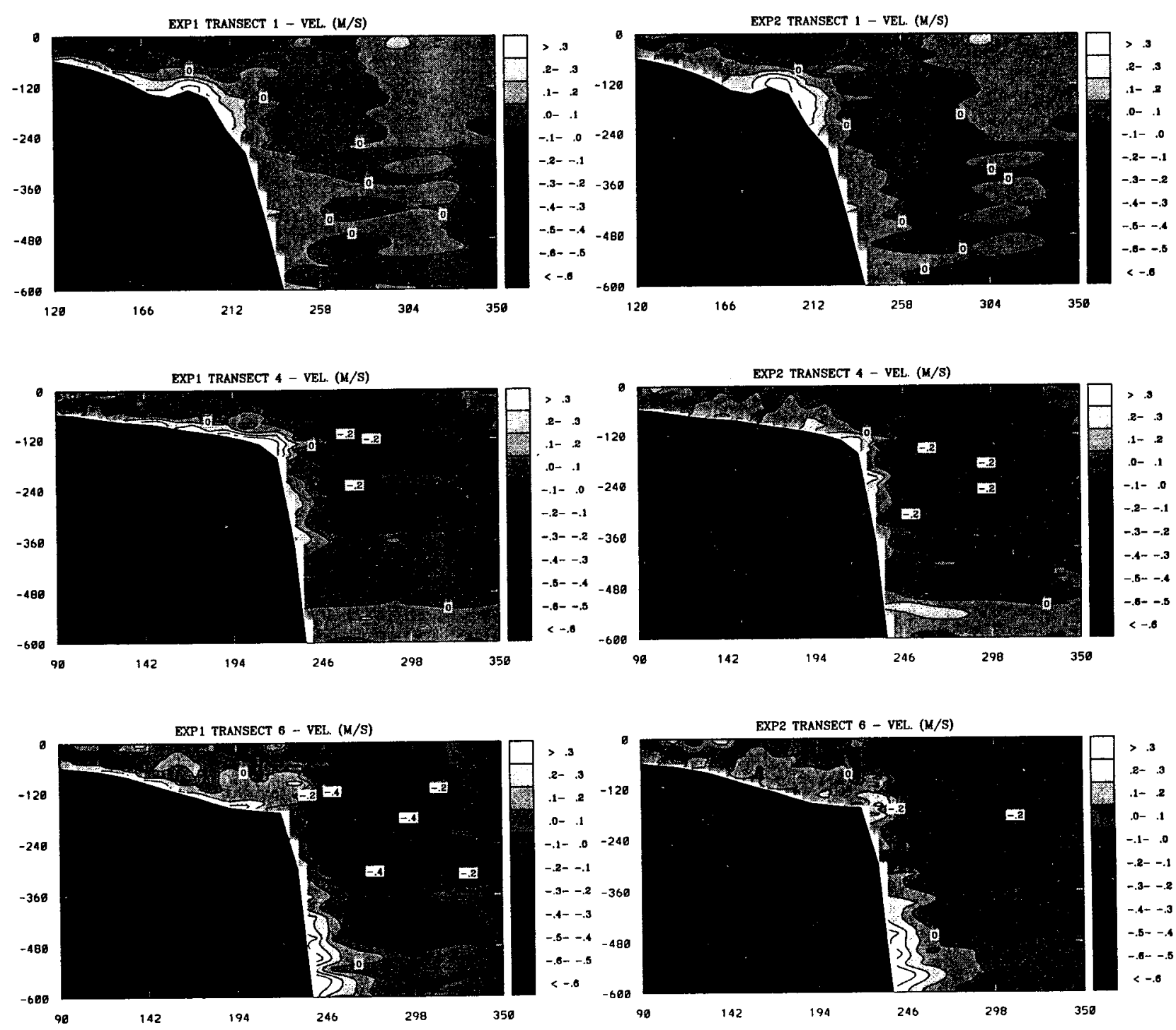

Fig. 3. Vertical sections showing the temperature and salinity distributions for the HM1 cruise along transects 1,4 and 6 . The $x$-axis represents the distance from the first grid point $(\mathrm{km})$ and the $y$-axis represents the depth $(\mathrm{m})$.

For the HM1 experiments (EXP1 and EXP2), vertical profiles of velocity (Fig. 6) are shown for the same transects discussed above. Using the $-0.1 \mathrm{~ms}^{-1}$ isoline as the lower bound for the Brazil Current velocity, it is observed that on Transect 1 (upper panel of Fig. 6) the Brazil Current front is clearly located near the coast, with its core inshore of the shelf break, reaching depths of $100 \mathrm{~m}$. On the middle transect (middle panel of Fig. 6), the main core of the current is now located near the continental slope reaching depths down to $350 \mathrm{~m}$. On the southernmost transect (lower panel), the Brazil Current core is found farther offshore, and reaches depths of approximately $500 \mathrm{~m}$.

The horizontal profiles of the velocity ficld produced by the numerical experiments for the surface and the depths of $100 \mathrm{~m}, 200 \mathrm{~m}$ and $500 \mathrm{~m}$, are presented for EXP1 (Fig. 7) and EXP2 (Fig. 8). In these vector plots, one can observe, as suggested by the thermohaline structure, the Brazil Current penetrating in the area surveyed from the 

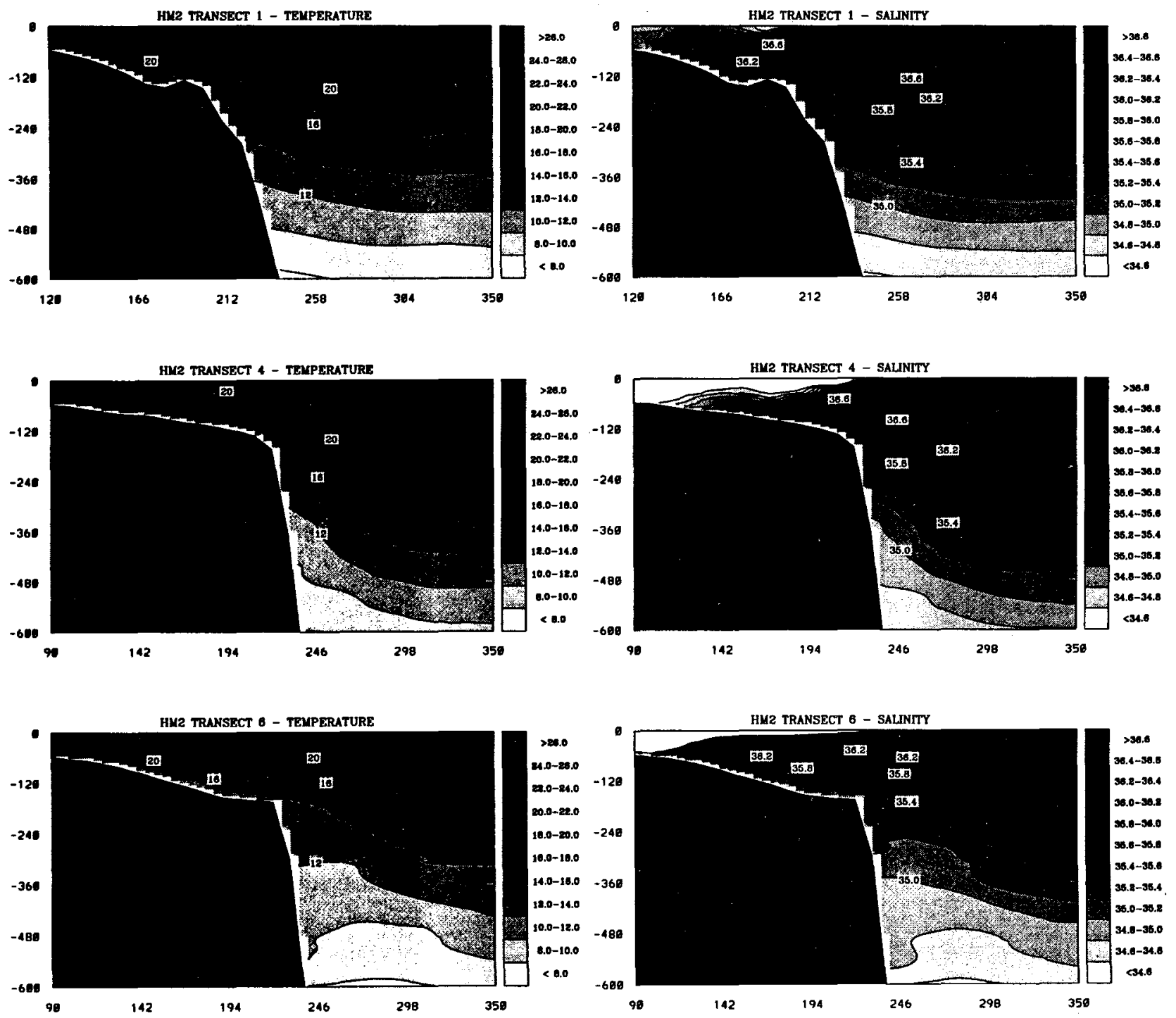

Fig. 4. Vertical sections showing the temperature and salinity distributions for the HM2 cruise along transects 1,4 and 6 . The $x$-axis represents the distance from the first grid point $(\mathrm{km})$ and the $y$-axis represents the depth $(\mathrm{m})$.

northeast, along a direction almost perpendicular to the shelf break. After reaching the $200 \mathrm{~m}$ isobath, however, the flow turns southward, meandering around the shelf break. The highest velocity values for the current are located in the upper $200 \mathrm{~m}$. In the lower regions, the velocity decreases monotonically down to $500 \mathrm{~m}$. Between $500 \mathrm{~m}$ and $700 \mathrm{~m}$ there seems to be a change in the velocity orientation, which may represent the AAIW flow to the north.

\section{The winter cruise - HM2}

The thermohaline structures for HM2 (Fig. 4) show patterns similar to those from the HM1, especially regarding the location of the Brazil Current front. That is, the front is located nearer to the coast on the northernmost transect and farther into the ocean in the southernmost one. The TW, on Transect 1 is limited to the regions above 120 $\mathrm{m}$, in oceanic regions, with water with characteristics of 


\section{HM1 - EXP1 and EXP2}

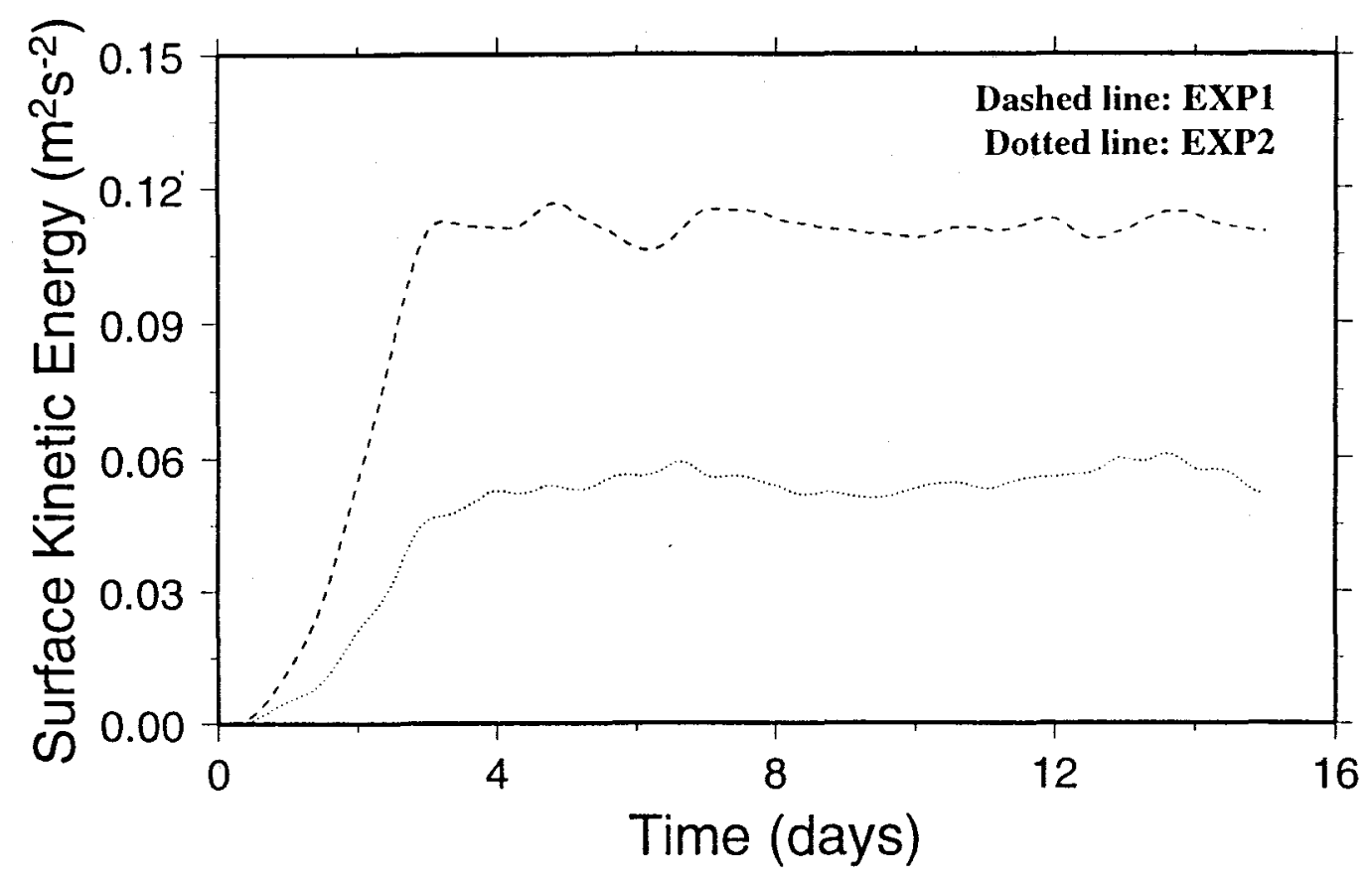

HM2 - EXP3 and EXP4

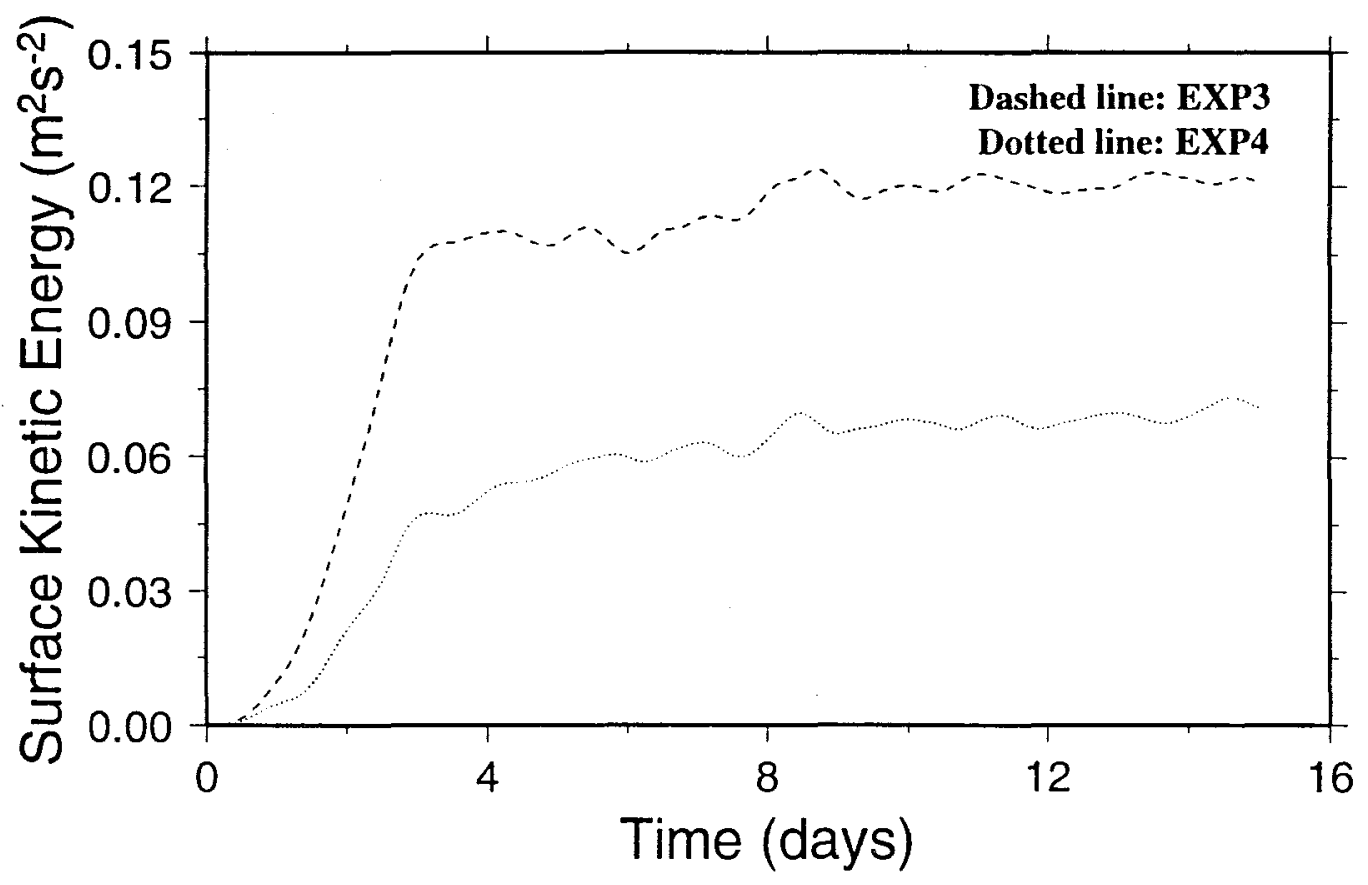

Fig. 5. Time-history of the kinetic energy for HM1 and HM2. 

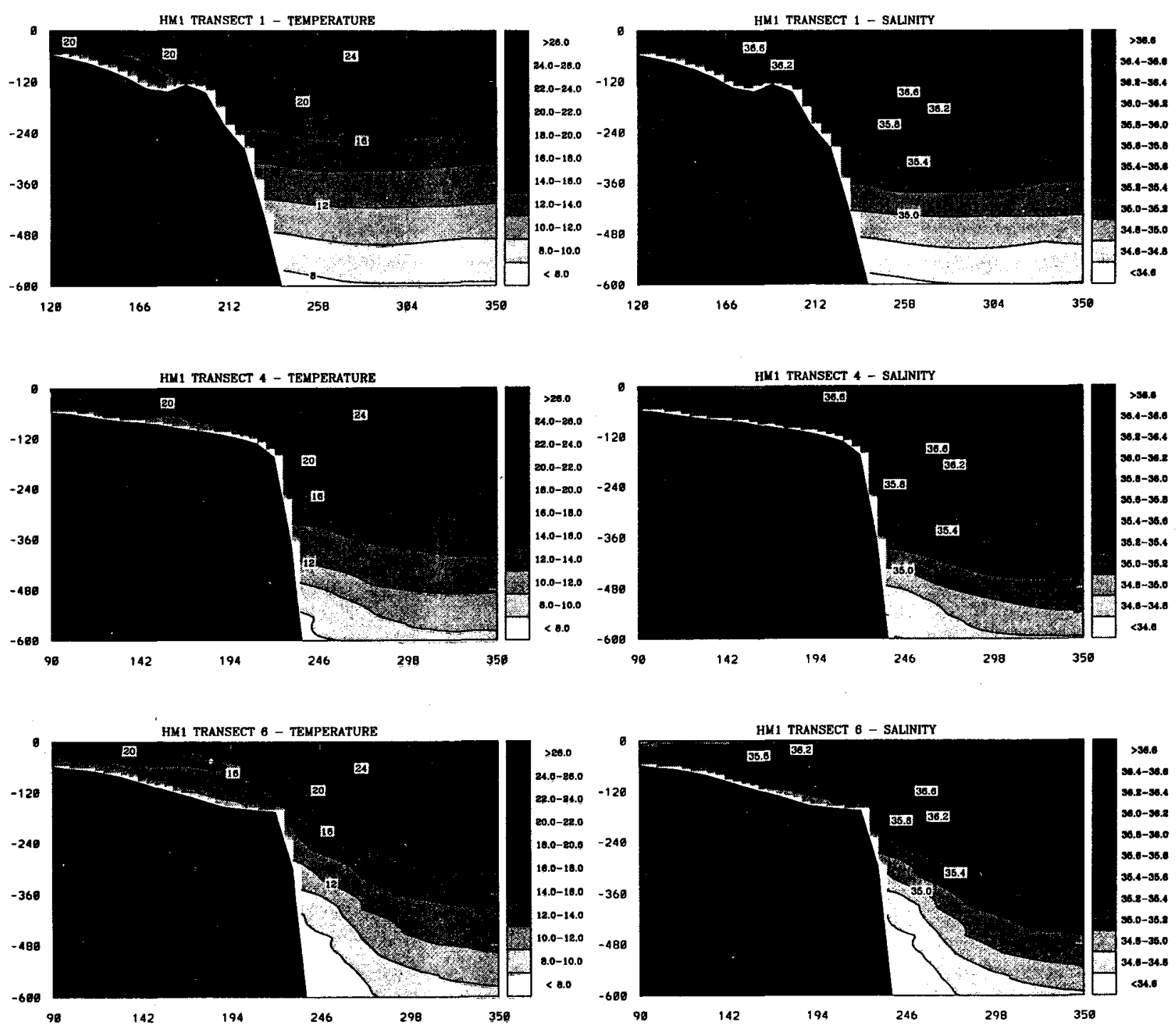

Fig. 6. Vertical sections showing the EXP1 and EXP2 velocity distributions along transects 1,4 and 6 . The $x$-axis represents the distance from the first grid point $(\mathrm{km})$ and the $y$-axis represents the depth $(\mathrm{m})$.

SACW below that level, in the thermocline. Penetration of SACW onto the shelf is also observed, with no connection between the continental shelf SACW and the oceanic SACW, again associated with the position of the Brazil Current front. On Transect 6, when the front is far from the coast, the SACW penetrates more freely onto the shelf, in comparison with transect 1 , where the front is located more inshore.

On the continental shelf, for Transects 1 and 4, the temperature field is quite homogeneous, without the strong seasonal thermocline observed during the summer cruise (upper and middle panels of Fig. 4). On Transect 6 (lower panel of Fig. 4), however, a thermocline is observed. This seems to be associated with the SACW penetration and the presence of a cooler mass of water coming into the domain from the south. Notably, this feature is also observed in the salinity field, already on Transect 4 (Fig. 4). A strong salinity gradient is observed in the upper layers of the shelf. This gradient, showing low salinity waters near the coast, is clearly not related to the SACW penetration and seems to 

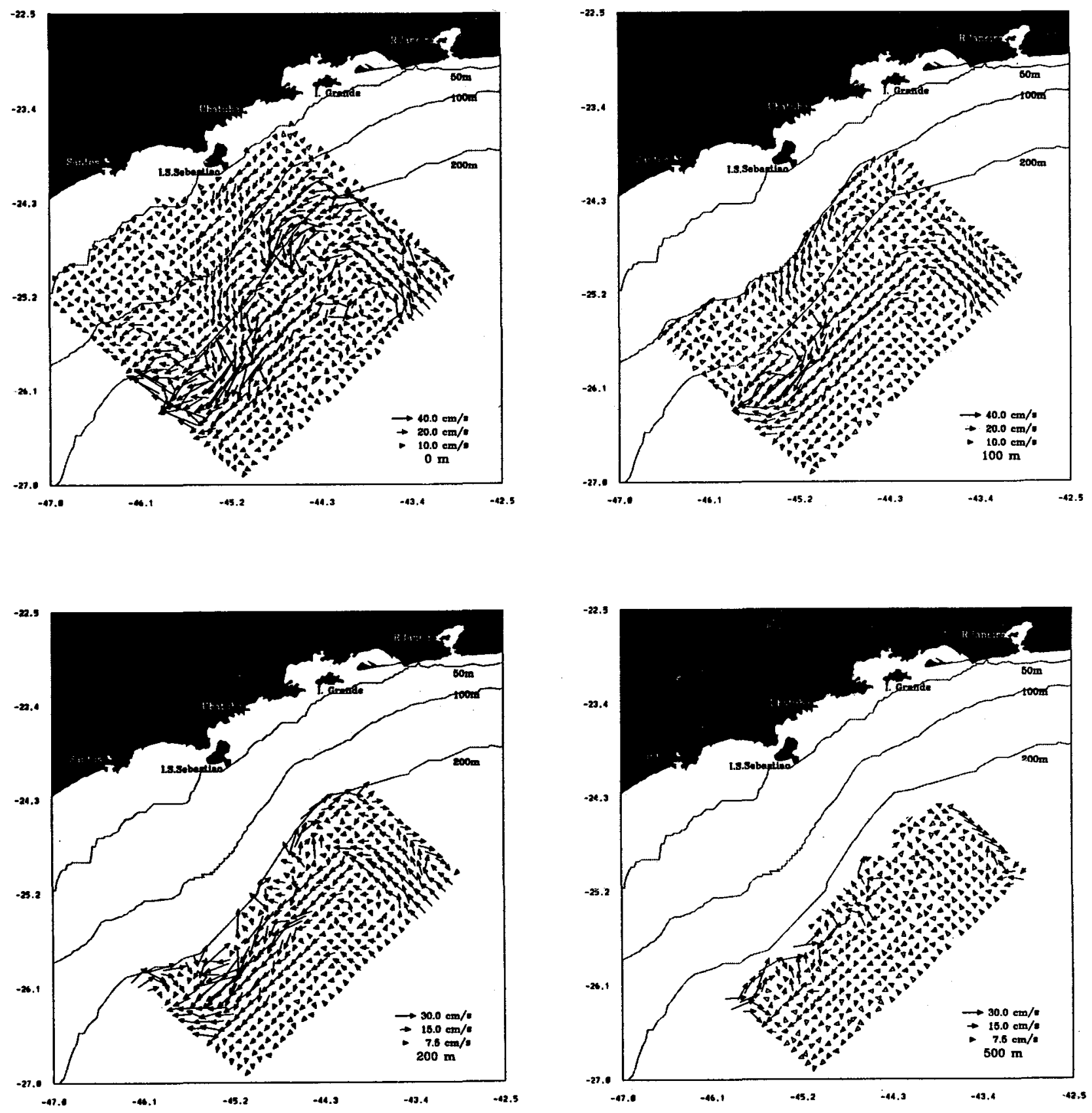

Fig. 7. Velocity fields for EXP1 at depths $0,100,200$ and $500 \mathrm{~m}$.

confirm the penetration of a coastal water coming from the south and flowing northward.

The velocity fields in EXP3 and EXP4, in analogy with the results found in HM1, show a Brazil Current intensifying and reaching greater depths as it flows to the south. On Transect 1 (Fig. 9), the main core of the current is located near the shelf and limited to the upper $100 \mathrm{~m}$. On the central transect (middle panel of Fig. 9), the main core 

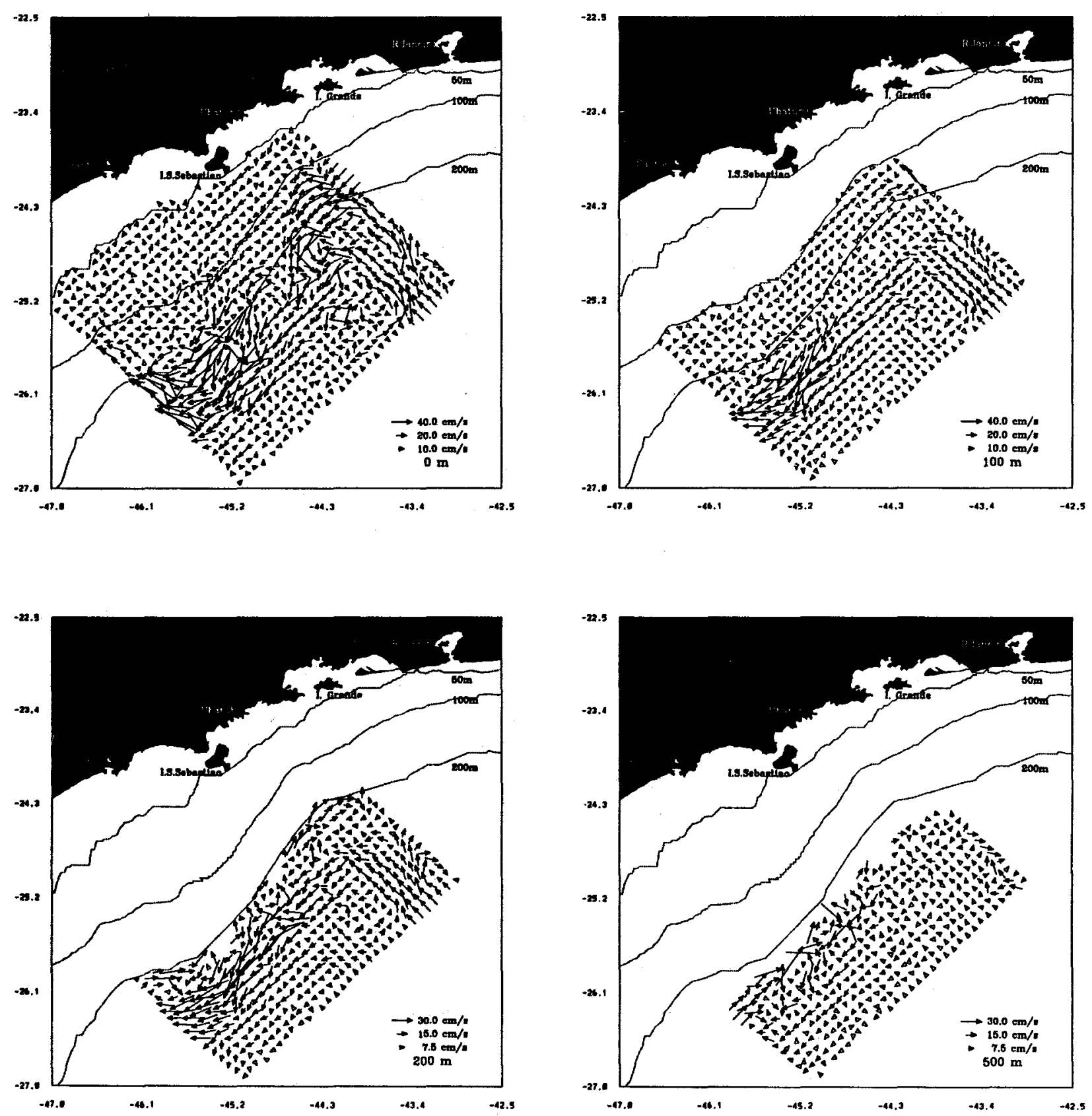

Fig. 8. Velocity fields for EXP2 at depths 0, 100, 200 and $500 \mathrm{~m}$.

of the current is located over the continental slope, reaching depths of $360 \mathrm{~m}$. On the southernmost transect (lower panel of Fig. 9), the current is most intense, and its core reaches to depths of $450 \mathrm{~m}$.
The horizontal velocity fields show a well marked current, as found in the results of the HM1 experiments. The horizontal velocity fields have thehighest values in the upper $100 \mathrm{~m}$, in both EXP3 (Fig. 10) and EXP4 (Fig. 11). 

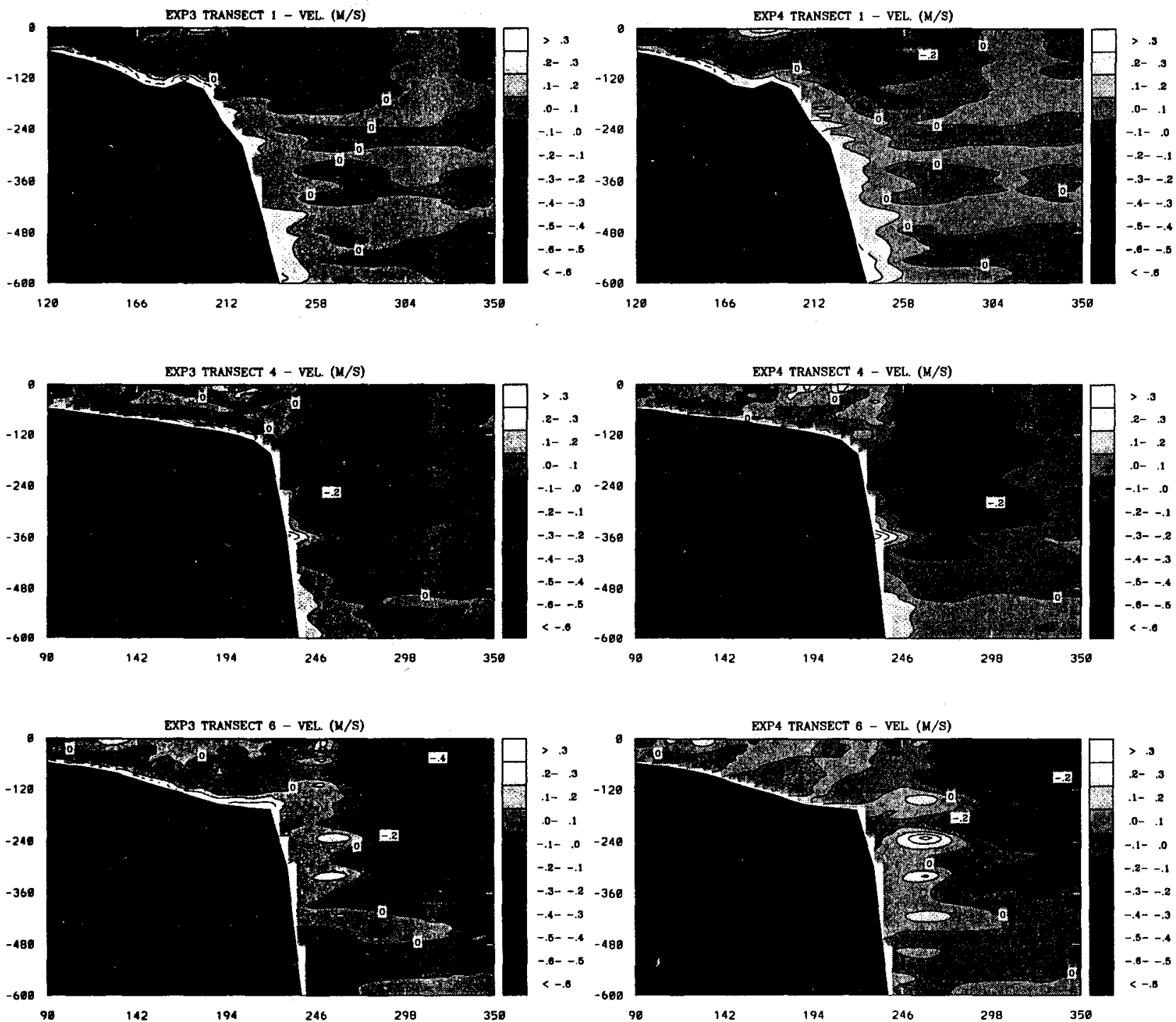

Fig. 9. Vertical sections showing the EXP3 and EXP4 velocity distributions along transects 1, 4 and 6 . The $x$-axis represents the distance from the first grid point $(\mathrm{km})$ and the $y$-axis represents the depth (m). 

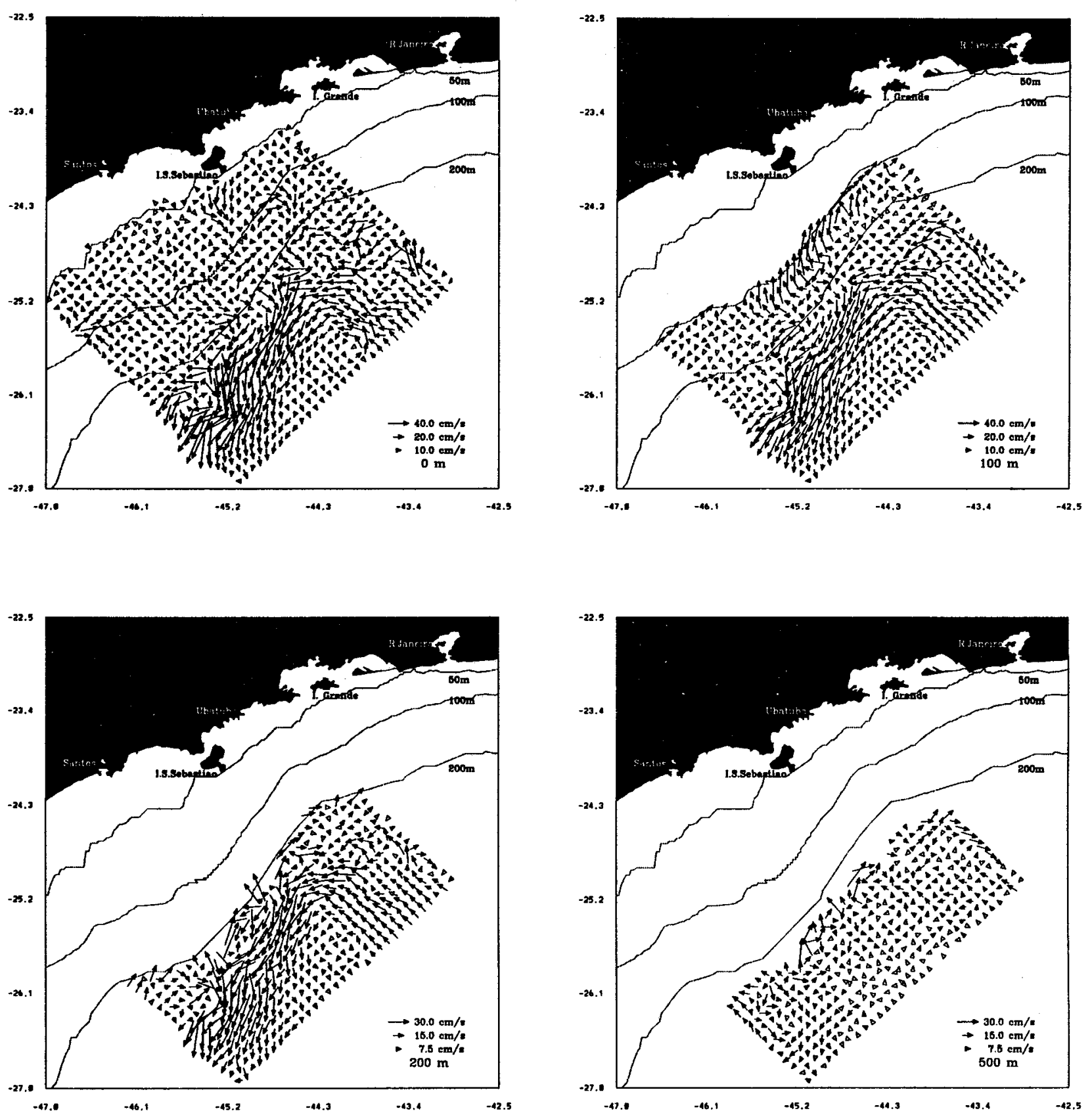

Fig. 10. Velocity fields for EXP3 at depths $0,100,200$ and $500 \mathrm{~m}$. 

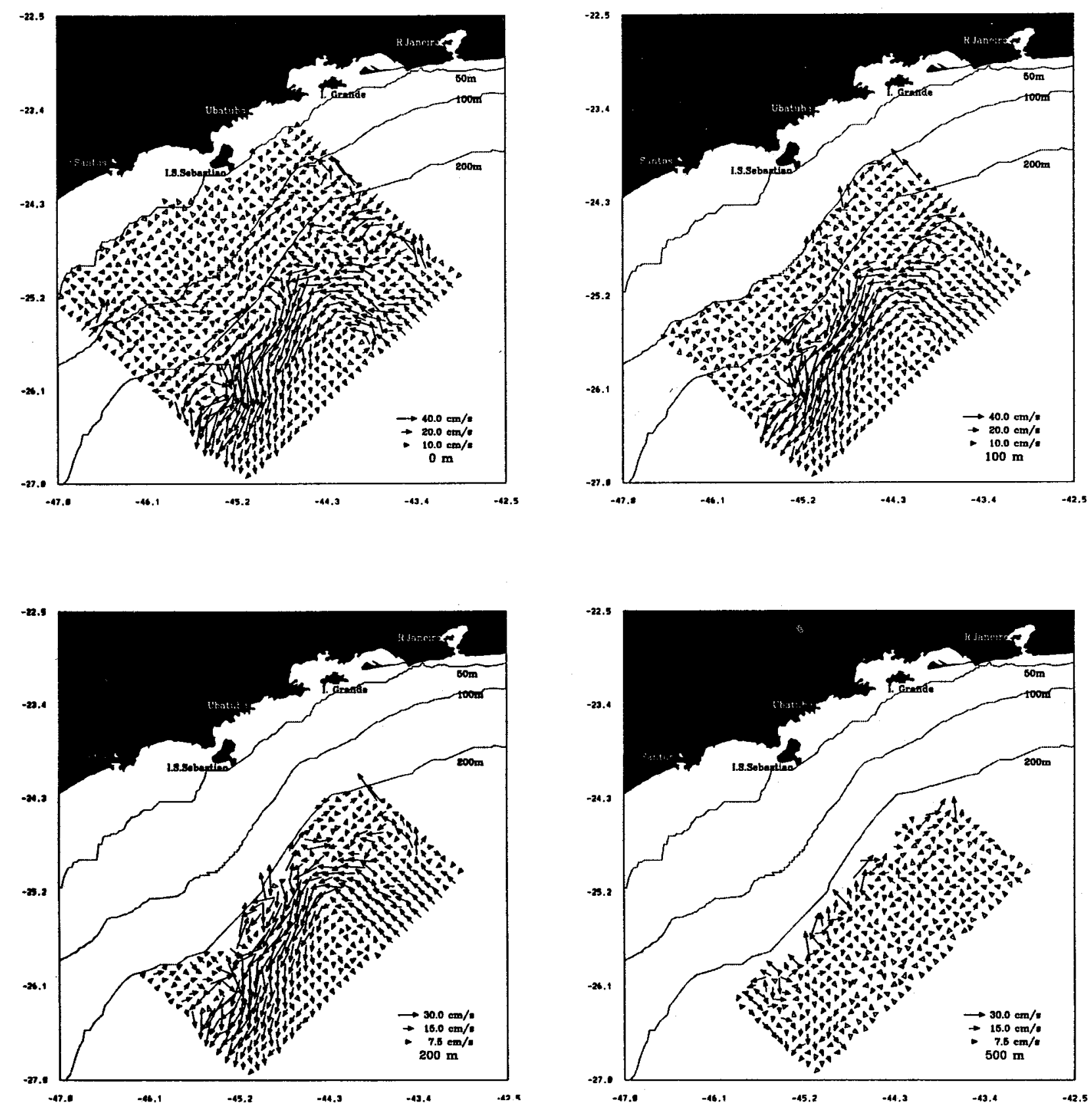

Fig. 11. Velocity fields for EXP4 at depths $0,100,200$ and $500 \mathrm{~m}$. 


\section{Discussion}

Except for the seasonal differences observed either in the thermohaline structure and in the velocity fields, a clear similarity was observed in the general results of HM1 and HM2. In both cases, a similar pattern for the Brazil Current was obtained, with the presence, in the two kinds of experiments for each cruise, of a cyclonic meander in the study area. As part of this meandering pattern, the current front is observed nearer to the coast in the vicinity of Ubatuba and farther into the ocean in the southern part of the domain.

In both cruises, the SACW penetration onto the shelf observed is probably due to the mechanism proposed by Campos et al. (1995), and seems to be associated with the cyclonic meandering of the Brazil Current; a topographic Rossby wave apparently induced by the upstream changein the coastline orientation.

Regarding the thermohaline structure, a pronounced thermocline in the shelf region is observed during the summer and in all transects of HM1 (Fig. 3)[see also Matsuura (1986)]. However, the expected wintertime homogeneous shelf water reported by Matsuura (1986) could only be observed in Transects 1 and 4 (Fig. 4). In Transect 6 , in a different pattern, a thermocline could be observed also in the winter of 1993 cruise.

\section{Acknowledgements}

The authors would like to express their gratitude to Dr. Jerry L. Miller (NRL/SSC) for his valuable help in the implementation of the POM for the simulations discussed in this paper. Project COROAS was funded by Fundação de Amparo à Pesquisa do Estado de São Paulo (FAPESP) - Proc. 91/0542-7, and by Conselho Nacional de Desenovolvimento Científico e Tecnológico (CNPq) Proc. 40.3007/91-7. This work is part of Project DABAS (FAPESP 94/3091-4).

\section{References}

Blumberg, A. F. \& Mellor, G. L. 1987. A description of a three- dimensional coastal ocean circulation model, In: Heaps, N. S. ed. Three dimensional coastal ocean models. Coastal and Estuarine Sciences, 4:1-16.
Campos, E. J. D. 1995. Estudos da circulaçāo oceânica no Atlântico tropical e na regiāo oeste do Atlântico subtropical sul. Tese de livre-docência. Universidade de Sāo Paulo, Instituto Oceanográfico. 114 p.

Campos, E. J. D. \& Olson, D. B. 1991. Stationary rossby waves in western boundary currents extensions. J. phys. Oceanogr., 21(8):1202-1224.

Campos, E. J. D.; Godoi, S. S.; Ikeda, Y.; Nonato, L. V. \& Gonçalves, J. E. 1994. Summertime thermohaline structure of the Brazil Current Region between Santos (SP) and Rio de Janeiro (RJ). Bolm Inst. oceanogr., S Paulo, 42(1/2):1-18.

Campos, E. J. D.; Gonçalves, J. E. \& Ikeda, Y. 1995. Water mass characteristics and geostrophic circulation in the South Brazil Bight: Summer of 1991. J. geophys. Res., 100(C9):18537-18550.

Castro Filho, B. M. 1985. Subtidal response to wind forcing in the South Brazil Bight during winter. Ph.D. Thesis. University of Miami. 211 p.

Chapman, D. C. 1985. Numerical treatment of cross-shelf open boundaries in a barotropic coastal ocean model. J. phys. Oceanogr., 15(8):1060-1075.

Cirano, M. 1995. Utilizaçāo de modelo numérico no estudo diagnóstico da circulação oceânica na bacia de Santos. Dissertação de mestrado. Universidade de São Paulo, Instituto Oceanográfico. 116 p.

Emilsson, I. 1961. The shelf and coastal waters off Southern Brazil. Bolm Inst. oceanogr., S Paulo, 11(2):101-112.

Evans, D. L.; Signorini, S. R. \& Miranda, L. B. 1983. A note on the transport of the Brazil current. J. phys. Oceanogr., 13(9):1732-1738.

Garfield III, N. 1990. The Brazil current at subtropical latitudes. Ph.D. Thesis. University of Rhode Island. $121 \mathrm{p}$.

Harari, J. 1984. Modelo numérico hidrodinâmico tri-dimensional linear da plataforma continental sudeste do Brasil. Tese de doutorado. Universidade de São Paulo, Instituto Astronômico e Geofísico. 203 p. 
Hellerman, S. \& Rosenstein, M. 1983. Normal monthly wind stress over the world ocean with error estimates. J. phys. Oceanogr., 13(7):1093-1104.

Ikeda, Y. \& Campos, E. J. D. 1995. Oceanic circulation in western region of the South Atlantic - The COROAS experiment. WOCE Panel, (61):9-11.

Levitus, S. 1982. Climatological atlas of the world ocean. NOAA Prof. Paper 13. 173 p.

Lorenzzetti J. A.; Tanaka, K. \& Wang, J. D. 1988. Simulação numérica da ressurgência costeira em Cabo Frio (RJ) através de um modelo em elementos finitos de duas camadas. São José dos Campos, INPE. (INPE-4502-RPE/561).

Matano, R. P. \& Philander, S. G. H. 1993. Heat and mass balances of the South Atlantic Ocean calculated from a numerical model. J. geophys. Res., 98(C1): 977-984.

Matsuura, Y. 1986. Contribuiçāo ao estudo da estrutura oceanográfica da região sudeste entre Cabo Frio (RJ) e Cabo de Santa Marta Grande (SC). Ciênc. Cul., S Paulo, 38(8):1439-1451.

Mellor, G. L. 1993. User's guide for a three-dimensional, primitive equation, numerical ocean. New Jersey, Princeton University, Atmospheric and Oceanic Sciences Program. 35 p.

Mellor, G. L.; Mechoso, C. R. \& Keto, E. 1982. A diagnostic calculation of the general circulation of the Atlantic Ocean. Deep-Sea Res., 29(10A): 1171-1192.

Mellor, G. L. \& Yamada, T. 1982. Development of a turbulence closure model for geophysical fluid problems. Revs Geophys. Space Phys., 20: 851-875.

Miranda, L. B. de 1985. Forma da correlação T-S de massas de água das regióes costeira e oceânica entre o Cabo de São Tomé (RJ) e a Ilha de São Sebastião(SP), Brasil. Bolm Inst. oceanogr., S Paulo, 33(2):105-119.

Miranda, L. B. de \& Castro Filho, B. M. de 1979. Condições de movimento geostrófico das águas adjacentes a Cabo Frio (RJ). Bolm Inst. oceanogr., S Paulo, 28(2):79-93.
Miranda, L. B. \& Castro Filho, B. M. 1982. Geostrophic flow conditions of the Brazil current at $19^{\circ} \mathrm{S}$. Ciencia interamer., 22(1/2):44-48.

Peterson, R. G. \& Stramma, L. 1991. Upper-level circulation in the South Atlantic Ocean. Prog. Oceanogr., 26(1):1-73.

Reid, J. L.; Nowlin, W. D. \& Patzert, W. C, 1977. On the characteristics and circulation of the Southwestern Atlantic Ocean. J. phys. Oceanogr., 7:62-91.

Semtner, A. J. \& Chervin, R. M. 1988. A simulation of the global ocean circulation with resolved eddies. J. geophys. Res., 93(C12):15502-15522.

Signorini, S. R. 1976. Contribuição ao estudo da circulação e do transporte de volume da corrente do Brasil entre o Cabo de São Tomé e a Baía de Guanabara. Bolm Inst. oceanogr., S Paulo, 25:157-220.

Signorini, S. R. 1978. On the circulation and the volume transport of the Brazil Current between the Cape of São Tomé and Guanabara Bay. Deep-Sea Res., 25:481-490.

Signorini, S. R.; Miranda, L. B. De; Evans, D. L.; Stevenson, M. R. \& Inostroza, H. M. 1989. Corrente do Brasil: estrutura térmica entre $19^{\circ}$ e $25^{\circ} \mathrm{S}$ e circulação geostrófica. Bolm Inst. oceanogr., S Paulo, 37(1):33-49.

Silva, M. P. 1995. Caracterização fisico-química das massas de água da Bacia de Santos durante o projeto COROAS. Verão e Inverno de 1993. Dissertação de Mestrado. Universidade de São Paulo, Instituto Oceanográfico. 135 p.

Smagorinsky, J. 1963. General circulation experiments with the primitive equations, I. The basic experiment. Mon. Weath. Rev., 91:99-164.

Sommerfeld, A. J. 1949. Partial differential equations in physics. New York, Academic Press. 335 p.

Stommel, H. 1965. The Gulf Stream. A physical and dynamical description. $2^{\text {nd }}$ ed. Berkeley, University of California Press. 248 p. 
Stech, J. L. 1989. Um estudo comparativo da dinâmica da circulação de inverno entre as plataformas continentais das costas sudeste do Brasil e dos Estados Unidos utilizando um modelo numérico. Tese de doutorado. Universidade de São Paulo, Instituto Oceanográfico. 224 p.

Sverdrup, H. U.; Johnson, M. W. \& Fleming, R. H. 1942. The oceans: their physics, chemistry and general biology. Englewood Cliffs, New Jersey, Prentice Hall. $1087 \mathrm{p}$.

Thomsen, H. 1962. Massas de água características del Oceano Atlantico - Parte Sudoeste. Publico Serv. Hidrogr. nav., Argent., H-632:1-27. 